\title{
Congenital atransferrinemia
}

INSERM

\section{Source}

INSERM. (1999). Orphanet: an online rare disease and orphan drug data base. Congenital atransferrinemia. ORPHA:1195

Congenital atransferrinemia is a very rare hematologic disease caused by a transferrin (TF) deficiency and characterized by microcytic, hypochromic anemia (manifesting with pallor, fatigue and growth retardation) and iron overload, and that can be fatal if left untreated. 